\title{
Andrushchenko v. INVESTIGATION OF THE UNDERWRITING PROCESS IN FACULTATIVE REINSURANCE, ITS FEATURES AND INFLUENCE ON BALANCE OF INSURANCE PORTFOLIO
}

Проведено аналіз процедури андерайтингу в факультативному перестрахуванні. Розглянуті ї особливості та вплив на збалансування страхового портфеля страхової компанії. Досліджені варіанти оформлення відносин між цедентом та перестраховиком під час здійснення факультативного перестрахування. Розглянуті бізнес-процеси управління ризиками під час здійснення вхідного та вихідного факультативного перестрахування.

Ключові слова: андерайтинг, перестрахування, факультативне перестрахування, облігаторне перестрахування, вхідне перестрахування, вихідне перестрахування.

\section{Introduction}

In Ukraine, under the influence of transformational processes, the economy is undergoing constant changes and shocks. These trends extend to all spheres of economic relations, including, in the insurance market, which is an important component of the national market. In the conditions of modern economic globalization, the formation of an effective reinsurance policy is an urgent problem for every insurance company. Recently, more and more attention to insurance companies in Ukraine is given to facultative reinsurance operations. Underwriting, as a process of accepting or transferring risk, in facultative reinsurance is one of the key elements in managing the financial stability of the insurer, since it allows improving the performance of the insurance company by redistributing risks and qualifying them.

Correctly planned and implemented underwriting policy in facultative reinsurance helps to get an optimally balanced insurance portfolio and ensure the financial stability of the insurance company and get the planned profit to its shareholders.

So, to create a balanced insurance portfolio of the insurance company, it is necessary, among other things, to carry out weighted and planned underwriting in facultative reinsurance.

\section{The object of research and its technological audit}

In order to effectively form an underwriting policy in facultative reinsurance, its features and impact on the balancing of the insurance portfolio have been explored. The question of underwriting in reinsurance and its peculiarities in facultative reinsurance is extremely relevant and little-investigated.

\section{The aim and objectives of research}

The aim of research is analysis of the underwriting features in facultative reinsurance and its impact on ba- lancing the insurance portfolio of the state in the current economic situation.

To achieve this aim, the following scientific tasks are defined:

1. To investigate the underwriting process in facultative reinsurance.

2. To identify separate business processes for incoming and outgoing reinsurance.

3. To consider economic relationships in the underwriting process in facultative reinsurance and highlight the interests of its main participants: reinsurant and reinsurer.

4. To prove that conducting underwriting in facultative reinsurance affects the balance of the insurance portfolio.

\section{Research of existing solutions of the problem}

The study of reinsurance deals with many scientists and practitioners.

Legislation stipulates that reinsurance is the insurance by one insurer (assignor, reinsurer) under the terms of the risk of performing part of their duties to the insurer from another insurer (reinsurer) of a resident or non-resident having the status of an insurer or reinsurer, according to the legislation of the country in which he is registered [1].

Reinsurance is a rather complex mechanism for managing insurance risk, so it provides for different methods of transferring risk.

In general, work with risks in reinsurance occurs on a permanent basis or at a time. Depending on the method of transferring risk to reinsurance, reinsurance operations distinguish between facultative, obligatory and facultative obligatory [2]. For the possibility of a more fundamental consideration of the features of facultative reinsurance, let's consider all methods of transferring risk.

Facultative - this method determines the complete freedom of the parties to the reinsurance contract. The assignor decides to transfer the risks or leave them on their own withholding, and the assignee has the right to accept or refuse to take risks. Facultative reinsurance provides for the transfer and execution of each risk separately. The 
contract of facultative reinsurance is a separate individual transaction, is, as a rule, in relation to one particular risk. A special feature of this method of reinsurance is the individual risk assessment and regulation by the insurance company of its own retention. Self-retention is an economically justified part of the insured sum, which the insurance company leaves on its responsibility [3]. Self-retention can be determined, both separately under the insurance contract, and for one risk, a number of risks and the like.

A prerequisite for concluding facultative reinsurance contract is a slip. Slip is a proposal document, sent to the assignee by the assignor and contains the main characteristics of the risk [4]. It includes information on the specifics of insurance risk and reinsurance coverage, including: the name and address of the insurer, information on the reinsurer, the type of reinsurance contract, the reinsurance object, the insured amount, reinsurance rate, self-retention, etc.

Undisputed advantages of the facultative reinsurance method is the possibility of choosing a reinsurer for reinsurance terms that are advantageous for him and use of reinsurance, where responsibility for risks can damage the financial stability of the insurer or when there is a need to expand the liability of insurance for unfavorable risks.

The disadvantages of this method include the following:

- without the consent of the reinsurer, reinsurer can't

change the terms and conditions of reinsurance;

- significant administrative costs for the maintenance and processing of facultative reinsurance;

- investigation of an individual risk gives certain information to competitors about the internal insurance and reinsurance policies of the reinsurer;

- absence of automatic updating of the optional cover;

- the need to constantly analyze the insurance port-

folio for risks, which it is necessary to reinsure.

Obligatory reinsurance operations provide for the obligatory transfer by the reinsurer of the previously agreed risks for part or the entire insurance portfolio and the obligations of the reinsurerto take the risks of the reinsurer in accordance with the terms of the reinsurance contract.

The reinsurance contract concluded in accordance with this method determines the liability of the parties, the reinsurance commission, coverage restrictions, reporting procedures and the like.

Reinsurance on an obligatory basis is universal, is the most widespread in practice and is used in all types of insurance and operates in most countries of the world.

The advantages of the obligatory method of reinsurance are:

- the possibility of increasing the volume of insurance and reinsurance operations;

- ensuring an even distribution of risks in the insurance portfolios of the assignor;

- the automatic risk acceptance mechanism allows to optimize costs associated with risk processing;

- development of long-term relations between the parties that forms an insurance and reinsurance history; - provision of guarantees of support from the reinsurer; - greater freedom of the assignor to conduct insurance operations.

The peculiarity of this reinsurance method is that when the risk does not fall under the terms of the obligatory contract or the insurance amount exceeds the limit of liability under the contract, there is a need for an additional contract for facultative reinsurance.

Facultative obligatory reinsurance provides for options for the assignor, and obligatory for the reinsurer. According to this method of reinsurance, the reinsurer necessarily accepts the risks caused by the contract.

Facultative obligatory reinsurance is used in reinsuring large and/or dangerous risks to prevent cumulation of the risks of the assignor when the capacity of the proportional contracts has been exhausted.

According to the form of risk distribution between the participants of the reinsurance process, reinsurance contracts are divided into two groups: proportional and disproportionate.

The use of reinsurance contracts is determined by the needs of the insurer (assignor) and the characteristic features, specificity of reinsurance objects. Correct combination of forms and types of reinsurance contracts will allow insurers to avoid many shortcomings in insurance activities.

In foreign practice, obligatory reinsurance is used more often, but in Ukraine preponderant proportional contracts prevail, although obligatory disproportionate reinsurance has recently been actively introduced.

The reasons for the advantages of facultative reinsurance in Ukraine include:

Obligatory form of reinsurance contracts is technically difficult:

- insurance companies do not have the necessary insurance portfolio to interest the reinsurer in the obligatory method of cooperation;

- insufficient experience in servicing disproportionate contracts;

- lack of a database for processing and obtaining relevant statistical and analytical information on losses for previous years;

- specifics of concluding and conducting reinsurance transactions on facultative and obligatory basis.

So, obligatory reinsurance takes place in relation to a fairly wide and formed insurance portfolio, but it is not beneficial to the reinsurer for small insurance portfolios. Considering that in the domestic market most insurance companies do not have such portfolios, this method of reinsurance is for them only a theoretical nature.

The registration of the relationship between the assignor and the reinsurer during the implementation of facultative reinsurance occurs, as a rule, according to one of the following options:

1. There is a general agreement on cooperation with facultative reinsurance and, on its basis, reinsurance contracts (cover notes).

When registering relations between cession participants under this option, the procedure for concluding a reinsurance contract on facultative basis is as follows. First, the reinsurer and reinsurant enter into an agreement on cooperation with facultative reinsurance, regulating the general conditions for the transfer of individual risks, the responsibility of the parties, the conditions and procedure for implementing reinsurance compensation, and the like. This contract does not contain data on risks, but only determines the methodology for their transfer. By signing this agreement, the reinsurer is not required to take risks from the insurer for reinsurance. Facultative reinsurance 
provides for coordination with the reinsurer of any risk or modification in each individual case.

Specific risks of the insurer, which he wishes to reinsure under the Cooperation Agreement from facultative reinsurance, he sends to the reinsurer in the form of a cover note. Cover note is a document that refers to a cooperation agreement and according to which each individual risk is transferred. The cover note, as a rule, contains information about the specific risk and conditions for its reinsurance (type of insurance, insurance territory, insurance subject, insured amount, self-retention, reinsurer's premium, etc.).

2. Each separate risk is transferred by a separate reinsurance contract.

In this variant of registration of mutual relations of the parties of reinsurance concerning each separate risk or group of risks which it is passed optionally, the autonomous reinsurance contract is concluded. This contract is, in fact, a separate full document, which reflects an exhaustive list of all the conditions of the reinsurance process and the interaction of the parties.

So, the optional method of transferring risks, in both the first and second versions, provides that, in accordance with the fact of each individual risk of the assignor, which he wishes to reinsure, the necessary data to the reinsurer for consideration and confirmation of the possibility of reinsurance are sent. This process is called the risk quotation. A certain list of risk characteristics and its content, together with the terms, the reinsurance program, and the reinsurance rate at which the reinsurer is willing to accept the risk, is called quotes. As a rule, the process of quoting risk at the stage of acceptance for insurance and at the stage of reinsurance is not much different. For each of the insurance products, there is a standard set of parameters necessary to assess the risk by the underwriter, and which are grouped and arranged in the form of an insurance application and a questionnaire. Based on the risk data obtained from these documents, the reinsurer's responsible employee decides on the attractiveness and acceptability for the insurance portfolio of the insurance company of this risk and calculates the reinsurance tariff. After receiving the quotation from the reinsurer, the assignor fills the cover note and sends it to the reinsurer. It is very important at what point the risk is considered transferred by the assignor and accepted by the reinsurer. The moment from which the reinsurer is considered at risk is to accept a cover note. To optimize the reconciliation process and establish the procedure for issuing the transfer of risks, as a rule, the acceptance is sent by e-mail in the form of a scanned version with the signature and seal of the reinsurer. Further, the sides are already exchanging the originals.

Scientists did not come to one point of view on understanding the underwriting. Let's give an example of several most useful and complete definitions.

So, underwriting as the main business process, which goal is management of the financial risks of the insurance company and ensure the profitability of the insurance portfolio, defines scientist O. Gubar [5]. This approach is too general and does not take into account other processes of the insurer's activities that are interrelated with underwriting.

Underwriting - as a complex work that is conducted by an insurer regarding accepting risks for insurance, including their evaluation, determining the possibility of insurance, choosing the optimal coverage, checking the compliance of risks and customers with the goals and objectives of the insurance company in terms of its financial stability, says Professor S. Osadets [6]. It is in this definition, in our opinion, that the above-mentioned omissions are taken into account.

The author's definition of underwriting in reinsurance is justified as a complex of interrelated activities of the insurer, including risk assessment, its quotes, the selection of the optimal reinsurance coverage and participation, if necessary, in settlement of claims [7]. These definitions integrate processes under the main insurance contract and reinsurance and settlement procedures.

A. Arkhipov [8] considers underwriting precisely in reinsurance, not only as the coordination of the price and terms of reinsurance of a particular risk or contract today, but also control over the overall state of its portfolio in a temporary and spatial apparent. An underwriting in reinsurance includes a system of measures: a painstaking preliminary study of risk (advanced risk assessment) of the definition of the tariff (more sophisticated premium rating) when it is necessary to introduce a management (department) to settle damages in reinsurance and risk management. The scientist concludes: «Underwriting in reinsurance is a system of measures, including a responsible preliminary study of risk, clarification of risk pricing, creation, if necessary, of new services for settlement of claims and risk management and conclusion of more binding contractual (agency) agreements with brokers».

\section{Methods of research}

The following methods are used for solving the task: analysis and synthesis, logical generalization, analogies, comparative comparison.

\section{Research results}

The question of underwriting in facultative reinsurance is little investigated and requires more attention from scientists.

Let's consider in more detail the underwriting process in facultative reinsurance. It can be conditionally divided into two parts: underwriting in the input and output facultative reinsurance.

In the original facultative reinsurance, it is suggested that underwriting be considered from a separate risk at all stages of its life, concerns the assignor.

Let's conditionally outline the following stages of risk life cycle for the assignor:

1. Stage of accepting the risk for insurance. The conclusion of the original insurance contract provides for the fulfillment of the terms of underwriting policy of the insurer. This document, as a rule, provides standard conditions for concluding insurance contracts by types of insurance with certain restrictions on individual risks (for example, restrictions on the insured amount, restrictions on certain risk categories (brand, model in motor insurance), restrictions on insurance objects (age of the insured cars in motor insurance, age and material of buildings in property insurance, etc.), etc.). If the risk parameters are beyond the specified limits, it is necessary to conduct an underwriting on an individual basis through a request and agreement with the responsible employee of the insurer. 
Given that the underwriting policy of the insurer provides and takes into account thereinsurance policy, it is at this stage that primary underwriting in reinsurance is carried out by determining the filling of the risk and calculating the original insurance tariffs, relying on certain parameters of reinsurance.

2. Stage of risk processing. At this stage, the responsible employee of the assignor makes a decision on the basis of already concluded insurance contracts, that is, already bearing portfolio responsibility. The main tasks at this stage are grouping and decomposition of risks. Grouping is understood as the definition of risk categories and parameters for transmission by individual groups or individual. Risk decomposition involves determining the content of each risk and assessing the acceptability and attractiveness of its components for the assignor's portfolio. Based on the latter, a decision is taken to transfer all or part of the risk in the perspective of its structure.

3. Stageof risk transfer. The assignor chooses a certain list of partners with whom he cooperates in reinsurance. At the same time, one of the main tasks of the insurer remains a permanent monitoring of both existing partners and potential participants of the insurance market. In order to select a specific reinsurer, the assignor sends requests to all partners to receive proposals for reinsurance. Further, on the basis of the obtained data and within the general reinsurance policy, a decision is made to documentation of the risk transfer, receipt of acceptances and the processing of original documents. Risk transfer, as a rule, is carried out according to the form of the reinsurance contract that is provided and convenient for the assignor.

4. Stage of the damage settlement. In the event that an insured event has occurred in the concluded and reinsured insurance agreement, the insurer's responsible employee is required to provide the reinsurer with the terms stipulated in the reinsurance contract and, in the process of the damage settlement, ensure the information of the reinsurer and, if necessary, the participation of its representatives. After making the payment, the assignor sends the claim to the reinsurer in the payment of the reinsurance compensation together with the package of necessary documents. After receiving the letter of claim and, if he does not have additional requests or objections on the reinsurance case, the reinsurer makes payment of his part of the refund within the terms stipulated by the contract.

5. Stage of re-agreement of reinsurance contract. Taking into account the characteristics of the underwriting year and on the basis of the re-agreement of original insurance contract, there is a need to re-agreement the reinsurance contract. As a rule, for a reinsurance contract for a new period, indicators and parameters of previous years are taken into account. However, changes in the transfer of specific risks are possible if the conditions for introducing a reinsurance policy and/or a list of reinsurance partners are changed.

In the incoming facultative reinsurance, let's decompose the underwriting process to the following stages:

1. Quotations of risk. At this stage, obtaining from the assignor risk parameters, the reinsurer conducts reinsurance underwriting and forms its offer in the form of quotes. If there is not enough information to complete the quotation, the assignor provided, the reinsurer requires it in full. However, in exceptional cases when there is a need for an operative solution of the set tasks, the reinsurer can provide indicative conditions for reinsurance protection, that is, specify not final parameters that can be corrected after obtaining full information about the risk.

2. Risk execution. After giving the quotation, the reinsurer receives a reinsurance contract from the assignor for acceptance. The contract of reinsurance, as already indicated, usually consists in the form of the assignor. After providing an acceptance, the reinsurer is considered at risk. In the future, the parties exchange original contracts.

3. Settlement of damages. If information is received from the assignor about the occurrence of an event that has insurance, the reinsurer registers the relevant information and, if necessary, takes part in the settlement of the insured event. After the provision of all the necessary documents, the reinsurer will pay the reinsurance indemnity within the terms provided by the contract.

4. Re-agreement of reinsurance contracts. After the end of the preliminary reinsurance contract and on the basis of the request of the assignor, the reinsurer, taking into account the underwriting and reinsurance policies, provides him with proposals for the contract renewal.

In the implementation of underwriting in facultative reinsurance there are a number of difficulties. For example, at moments when the insurer needs to promptly decide on the conclusion of the original insurance contract, then requires reinsurance, it does not always have time for a risk quotation from the reinsurer. In this case, the responsible employee of the insurer has, at his discretion, guided by practical skills to promptly take a decision and calculate the conditions for concluding an insurance contract without information from the reinsurer. The urgency of this issue should, first of all, in the view of balancing the insurance portfolio and the mathematical appropriateness of working with risk. On the one hand, there is an original premium under the insurance contract, containing loads; on the other hand, there is a need to place part of the risk from the reinsurer for a certain reinsurance premium, the resource for payment of which must be taken into account at the original rate.

Reinsurance has an important basis: the insurer is liable to the insurant, despite the fact that the risk can be reinsured. That is, despite the reinsurance contract, the insurer must pay the insurance indemnity to the insured in full and only then receive a part of the damage from the reinsurer in accordance with the responsibility transferred to him. This aspect should be taken into account by the financier of the insurer to ensure, if necessary, the entire amount of payment until the settlement of obligations with the reinsurer, as it can affect the financial stability of the insurer. Financial sustainability is the ability to fulfill the obligations assumed under insurance contracts, despite external factors (for example, inflation, a decrease in revenues, a rise in prices when settling damages, etc.) [9]. The insurance policy, as a rule, may not even know about reinsurance, since reinsurance is the internal policy of insurance companiesthat does not concern primary or original risks.

The question of underwriting in facultative reinsurance as one of the ways to balance the insurance portfolio of an insurance company and protect it from insolvency and bankruptcy cases is relevant for the insurer, and therefore requires a systematic and balanced approach with the aim of developing an optimal and efficient balanced reinsu- 
rance policy overall. The insurance company independently develops an effective balanced reinsurance policy, setting priorities in its activities and choosing path of stabilization and upgrading of insurance portfolio [10].

\section{SWOT analysis of research results}

Strengths. The strength of research is a detailed consideration of the specifics of underwriting in facultative reinsurance and its impact on the balance of the insurance portfolio of the insurance company.

Weaknesses. The weak side is the lack of awareness of this issue in the scientific literature, which makes it impossible to refer to other scientific concepts and studies of differences in the views of the author on this process.

Opportunities. Opportunities for further research are borrowing the experience of foreign countries to improve the underwriting process in facultative reinsurance and its implementation in the domestic insurance and reinsurance space.

Threats. Threats to the results of conducted research are the deficit of single-subject specialists in underwriting and reinsurance. Only a few universities in the country are training insurance specialists, however, without indepth excursions to these processes. Also, the threat is a lack of intensive exchange of information and gaining experience with foreign colleagues.

\section{Conclusions}

1. The question of underwriting in insurance is well investigated in scientific domestic and foreign works. At the same time, underwriting research in facultative reinsurance today remains practically without the attention of scientists. The analysis of the theoretical bases of underwriting in facultative reinsurance allowsto conclude that it is necessary and influence the balance of the insurer's insurance portfolio.

2. Separate business processes for incoming and outgoing reinsurance have been singled out through the prism of research of the underwriting process in facultative reinsurance, and recommendations for their implementation have been described.

3. The analysis allowsto explore economic relationships in the process of underwriting in facultative reinsurance and highlight the interests of its main participants: reinsurer and reinsurant.

4. The conducted research proves that a correct and balanced underwriting policy in facultative reinsurance positively influences the financial stability and balance of the insurance portfolio of the insurance company.

\section{References}

1. Pro strakhuvannia [Electronic resource]: Law of Ukraine from March 7, 1996 No. 85/96-BP. - Available at: \www/URL: http://zakon5.rada.gov.ua/laws/show/85/96-вр

2. Marcheva, I. A. Strahovanie [Text]: Handbook / I. A. Marcheva. - Nizhny Novgorod: Nizhny Novgorod State University, 2012. - $122 \mathrm{p}$

3. Vovchak, O. D. Strakhova sprava [Text]: Handbook / O. D. Vovchak. - Kyiv: Znannia, 2011. - 391 p.

4. Fysun, I. V. Strakhuvannia [Text]: Handbook / I. V. Fysun, H. M. Yarova. - Kyiv: Tsentr uchbovoi literatury, 2011. - 229 p.

5. Hubar, O. Ye. Anderaitynh v provesno-oriientovanii systemi upravlinnia strakhovoiu kompaniieiu [Text] / O. Ye. Hubar // Proceedings of Scientific Works of Cherkasy state technological university. Series: Economics. - 2012. - Vol. 30, Part I. P. 72-73.

6. Osadets, C. C. Strakhuvannia [Text]: Handbook / C. C. Osadets, T. M. Artiukh, V. L. Babko et al.; ed. by S. S. Osadets. Kyiv: KNEU, 2002. - 570 p.

7. Andrushchenko, V. I. The Essence and Functions of Underwriting in the Reinsurance [Text] / V. I. Andrushchenko // Business Inform. - 2016. - No. 10. - P. 325-329.

8. Arhipov, A. P. Anderraiting v strahovanii. Teoreticheskii kurs i praktikum [Text]: Handbook / A. P. Arhipov. - Moscow: Yuniti-DANA, 2007. - $240 \mathrm{p}$.

9. Bazilevich, V. D. Strahovoe delo [Text]: Monograph / V. D. Bazilevich, K. S. Bazilevich. - Ed. 6. - Moscow: Znanie, 2008. $1019 \mathrm{p}$.

10. Andruschenko, V. I. Perestrahovanie kak instrument finansovoi ustoichivosti strahovshchika [Text] / V. I. Andruschenko // Zbirnyk tez dopovidei XI Mizhnarodnoi naukovo-praktychnoi konferentsii «Yevropeiskyi vektor rozvytku strakhovoho rynku Ukrainy». - Kyiv: Edelveis, 2016. - Vol. XI, No. 1. - P. 6.

\section{ИССЛЕДОВАНИЕ ПРОЦЕДУРЫ АНДЕРРАЙТИНГА}

\section{В ФАКУЛЬТАТИВНОМ ПЕРЕСТРАХОВАНИИ, ЕЕ ОСОБЕННОСТЕЙ} И ВЛИЯНИЕ НА СБАЛАНСИРОВАННОСТЬ СТРАХОВОГО

\section{ПОРТФЕЛЯ}

Проведен анализ процедуры андеррайтинга в факультативном перестраховании. Рассмотрены ее особенности и влияние на сбалансирование страхового портфеля страховой компании. Исследованы варианты оформления отношений между цедентом и перестраховщиком при осуществлении факультативного перестрахования. Рассмотрены бизнес-процессы управления рисками при осуществлении входного и выходного факультативного перестрахования.

Ключевые слова: андеррайтинг, перестрахование, факультативное перестрахование, облигаторное перестрахование, входящее перестрахование, исходное перестрахование.

Andrushchenko Vitaliy, Director of Underwriting and Reinsurance Department, JSC «Indigo Insurance Company», Kyiv, Ukraine, e-mail: z-1312@bigmir.net, ORCID: http://orcid.org/0000-0003-0597-3189 